\title{
Re-Thinking the Subject of Africa's International Relations
}

\author{
Prof. Dr. Leo E. Otoide*
}

The general subject of International relations has engaged enormous inquiries. ${ }^{1}$ The classical and empiricist schools raise, in part, intriguing questions of identity concerning the study of international relations; the obtrusive inquiry of identity concerning the study of international relations; the obtrusive inquiry on functionality, and indeed, whether international relations is a discipline with a clearly identifiable subject matter. ${ }^{2}$ Issues on methodology approaches and conceptualizations are also generating inquires. ${ }^{3}$ The diversity of these arguments and interests, buttresses the strength as well as the eclectic character of the subject of international relations.

It may be argued that these general theories of international relations to which we have alluded, are not geographically specific. This does not censure the fact that Africa, particularly pre-colonial Africa, has not had appreciable consideration in the maze of discourse of the subject of international relations. Precolonial African institutions and structures are said to lack the indices of statehood, which are the parameters for participation in international relations. It is further asserted that African states were disparate and so, could not maintain regular relations with each other as to be capable of being implicated in a generalized war. ${ }^{4}$ In essence, the viability of pre-colonial structures in Africa and their positive role in international relations has not been acknowledged.

Two decades ago, J.F.A. Ajayi significantly addressed the understanding of issues in African international relations. ${ }^{5}$ The issue remain relevant today. Ajayi

Dr. Leo E. Otoide is a Professor in the Department of History, University of Benin, Benin City, Nigeria.

1. K. Knoor and J.N. Rosenau (eds.). Contending Approaches to International Politics. Princeton: Princeton University Press, 1969; M.A Kaplan, System and Process in International Politics, New York : 1957; H. Morgenthau, Politics Among Nations: The Struggle for Power and Peace, New York: Knopf, 1948; M. Wright, Power Politics, Harmondsworth: Pengium, 1979.

2. M.A. Kaplan, "Is International Relations a Discipline ?" Journal of Politics, Vol. 23, 1961, pp. 462-476.

3. C. Mc Clelland, "The Function of Theory in International Relations", Journal of Conflict Resolution, Vol. IV, 1960, p. 307; S. Hoffmann, " International Relations : The Long Road to Theory" World Politics, Vol. II, pp. 356-360; H. Bull, "International Theory : The Case for a Classical Approach", World Cervenka, Vol. XVIII, No. 3, pp. 361-377; M. Kaplan, "The New Great Debate : Traditionalism Versus Science in International Relations", World Politics, Vol. 19, No. 3, pp. 1-20.

4. A Short, "History and Theory in International Relations: Some Observation for Nigeria", Nigerian Journal of International Affairs, Vol. 8, No. 1, 1982, p. 78.

5. J.F.A. Ajayi, "Recent Studies in West African Diplomatic History", Nigerian Journal of International Affairs, Vol. 1, No. 1, July, 1975, pp. 39-46. 
also decried the poverty of literature in African internal relations arising from what seems like a concerted pre-occupation by historians including Africans to neglect its study. ${ }^{6}$ Beyond Ajayi the pioneering works of Robert Smith, Adu Boahen ${ }^{7}$, J.F. Fynn, ${ }^{8}$ Oshuntokun ${ }^{9}$, and Asiwaju ${ }^{10}$ have not been substantially complemented.

African universities may indeed be intrigued with the study of international relations but they are enmeshed in rigid compartmentalization. Nigerian universities, for example, exhibit intellectual frigidity, perhaps borne out of a misconceived notion of assumed monopoly of relevance. Nigerian university scholars, as elsewhere in Africa, merely replicate the methodology and orientation they inherited from their places of training-Britain or America, and have not appreciated the peculiar intricacies in the evolution of African international relations and so seek to evolve a "home-grown" methodology for its study. What may also have eluded most academic study departments is that the subject matter of international relations is multidisciplinary. The mutuality of certain disciplines particularly history and political science, has hardly been appreciated by most Nigerian academics. Given these facts, there is an absolute need to close ranks and reflect deeply on the study of African international relations so that the subject would be more robust in content and orientation.

The problem of international relations in Africa requires deep appreciation and a wide breath of study. For a start, this paper would only to attempt to establish the possibilities of African international relations, its historical character and ramifications. The paper would show the evidence of diverse and sophisticated international relationships. Colonialism challenged the capacity of Africans to devise new methods and concepts of inter-relationships. At independence, Africa entered the phase of a world system that she never initiated. The processes of adjustment and adaptation invariably made her an effective and important actor in shaping the global system. The paper finally looks at issues in intra-African relations and Africa's capacity in determining the course of interactions in the international system.

\section{The Framework of Pre-Colonial States as Prelude to Inter-State Relations}

The boundary is a key element for defining statehood. It is the feature that provides the basis for reference to a distinct but holistic entity that participates in

6. $\quad$ R.S. Smith, "Peace and Palaver: International relations in Pre-colonial West Africa", Journal of African History, Vol. XIV, No. 4, 1973, pp. 599-621.

7. A. Boahen, "Asante-Dahomey Relations in the $14^{\text {th }}$ Century", Ghana Notes and Queries, No. 7, January 1965; A. Proahen, "Traditional African Diplomacy and Diplomatic Techniques" Paper Presented at the International Congress of Africanists, December, 1973 Addis Ababa.

8. J.F. Fynn, Asante and Its Neighbours 1700-1807, Evanston, 1971.

9. O. Oshuntokun, Equatorial Guinea-Nigeria Relations: The Diplomary of Labour, Ibadan: Oxford University Press, 1978, pp. 105-120.

10. A. I. Asiwaju, "The Concept of Frontier in the Setting of States in Pre-colonial Africa", Presence Africaine, Special No. 32/34, 1984, pp. 45-46. 
the international system on a level of formal equality and mutual acceptance. The boundary defines a statutory limit and facilities of the identification of people within a territorial framework who can lay claim to being integrated by a system of law. ${ }^{11}$

Scholars are in unison that the boundary indicates a limit. What are in contention are its physical representation and the interpretation of its usage. The attempt to impose a European understanding of boundaries on the African State system and use it as a basis for analysis is misleading. It demonstrates a lack of appreciation of the peculiar circumstances of African states and an attempt to divest Africans of their culture. African Empires such as Benin, Dahomey, Ghana, Mali, Songhai and Abyssinia had territorial limits and spheres of interest, which were well known. Even though frontiers were fluid, which was necessitated by their historical realities, states recognized their juridical limits. ${ }^{12}$ In some cases, States agreed on certain landmarks such as the Iroko tree, an anthill or some other natural landmarks such as rivers, mountains or valleys as defining the limits of political authority. In modern Tanzania area, for example, evolved a system of planting boundary hedges as a method of distinguishing between territorial limits. In Somali, there was the practice of cutting marks on the bark of trees to indicate territorial limits. The Fulani and Massai herdsmen knew the extent to which they could graze without infringing on the territorial rights of others.

While the European boundary acted as a limit, as did the African frontier, both civilizations had different attitudes to the concept of limit. In the traditional African society, the boundary did not imply as in the European sense a point of separation. Rather, it was seen as a point where the interest of one state attained a type of union with the interest of the other. It provided opportunities for interethnic contact since both communities could come together to offer common sacrifices at the boundary for their general good. In the West, boundary pillars and posts were and are not only meticulously laid but also traced on maps and measures instituted to control movement. In the traditional African society, people moved freely across agreed boundaries. The member of one community could seek the consent of the other to own farmlands, without necessarily living there. Long distance trade in most traditional African societies actually took place in markets situated on the boundaries between two states. There was a great deal of cultural interaction particularly with regard to marriages. So, traditional boundaries not only defined the jurisdictional limits of states. They were also instruments for nurturing and strengthening inter-state relations.

Given these parameters, the derogatory references to statelessness in Africa cannot be tenable. Tiv, Jukun, Ashanti, Igbo, Massai, Acholi, all had structures and organizations and cannot be easily dismissed as stateless. Ignorance of the

11. F.S. Northedge, The International Political System, London: Faber and Faber Limited, 1976, p. 92.

12. A.P. Bigham, "Principles in the Determination of Boundaries", The Geographical Review, VII, 1919. 
African past cannot give validity to present erroneous positions in the discourse on state and sovereignty in pre-colonial Africa.

\section{Diplomacy of State Formation and State Building}

Antecedents of diplomacy in pre-colonial Africa have been traced to the very early period of state formation. The evolution of Africa's earliest states from disparate and perhaps highly heterogeneous and conflicting units involved studied acts of the practice of conciliation, persuasion, ritualizing and coordination in other to achieve co-existence. ${ }^{13}$ The merging of African communities by skill of statesmanship and, perhaps too, magical powers as in the case of Okonfo Anokye in Ashanti, is particularly instructive. Several state systems in Africa evolved by persuasive efforts and a general appeal to the possibilities of collective benefits.

It is within this context that we can appreciate, for example, the craft and ritual involved in the evolution of the Great Empire of Mali. The earliest King of Mali was Maghan Kon Fatta. The fortunes of Mali were said to have changed with his strange encounter with Sogolon Kedjon, the mother of Mari Djata, later to be known as Sundiata. By a curious management of sorcery, magic and force, Sundiata and his followers brought to fruition the Madingo Kingdom of Mali. In Southern Africa, the whole process of expansion and consolidation of the Zulu Kingdom was by astute persuasion and military strategy. Also, in the Mfecane period the history of the southern Bantu tribes was characterized by a series of subdivision leading to migrations and land acquisitions.

By the eighteenth century, Zululand and Natal had become over crowded. A process of aggregation was developed as a strategy for survival bringing about large and formidable blocs such as the Ndwandwe, under Zwide and Ngwane Sobhuza and Mthethwa under Dingiswayo. This was accompanied by a revolution in military organization. What followed was the exploitation of craftsmanship and skill. This saw the emergence of Shaka, the Chief of what was then a small insignificant clan of Zulu. Shaka developed for the Zulu State intrinsic organizational principles, strict military discipline, order and consultation. The Zulu military machinery (Indunas) was beyond a mere coercive instrument. It facilitated diplomatic understanding and initiative among the various clusters that constituted the Zulu Kingdom. ${ }^{14}$

In addition, Borno Kingdom was a classic example of African craftsmanship in state formation, treaty making and obligation as well as tribute administration and regulation. Ali Gaji laid the foundation of the Borno Kingdom in the fifteenth century. This was after the collapse of the first Seifuwa state of Kanem. The major obstacle to building a state was the emergence of various semiautonomous groups and clans who were antagonistic to the Seifuwa ruling dynasty. Through the period of Mai Dunama Dabbalemi, culminating in the relocation of

\footnotetext{
13. Ajayi, f.n. no. 5, pp. 39-46.

14. O. Cooper, The Zulu Aftermath: A Nineteenth- Revolution in Bantu Africa, London: Longman, 1966, pp. 24-53.
} 
the Seifuwa in the new capital of Gazargamo, there was a continuous manipulation of circumstance to achieve state survival. The second Seifuwa dynasty emerged after periods of civil strife and chaos. This attests to the fact that a strong military organization is an important factor in state security and consolidation. Coupled with this was the system of administration, which allowed sufficient delegation of authority and flexibility.

The subsequent long drawn out battle between the Bulala of Kanem and Mai Idris Alooma of Borno was settled by the conciliatory gestures of one of the leaders of the Bulala, Muhammed Ibn Abdullahi. This paved the way for consultations between Borno and Kanem resulting in a treaty of mutual understanding between Borno and Kanem by which Borno took over part of Kanem and the rest was given to Muhammed Ibn Abudllahi to rule. Diplomatic relations were at ambassadorial level between Bornut and Egypt as well as with Turkey and Morocco to as far back as the eleventh century. These endeavors in diplomacy were conceived and executed by organized and systematic political machinery.

Methods for the establishment of diplomatic terms and recognition of immunities were inherent in early inter-state relations in Africa. For example, between the coastal states and the hinterlands there were relationships organized principally around trade and the security of trade routes. In East Africa, the popularity of the Nyamwezi was derived essentially from the economic network in which the Nyamwezi traders engaged. The traders carried the prestige, image and culture of their state and stamped them on other trading communities beyond their borders. Regulations concerning trade were also meticulously arrived at and adhered to by all parties.

Ambassadorial duties carried with it aura and respect. In the Gold Coast for example, those who performed the duties of the ambassador were referred to as the inquest which implied the international capacity of the holder of that office. Between Benin and Warri Kingdom regular liaison officers maintained relationships. In fact, Benin Kingdom sent ambassadors to the court of Portugal just like Agaja of Dahomey frequently did to Whydal. The Kingdom of Allada had emissaries in Europe. The Fante confederacy and the management of her external relation was also a case of diplomatic initiative between states in pre-colonial Africa. The Ekitiparopo, in 1878, which was an anti-lbadan coalition, was a case of states driven coalitions and alliances. In Oyo empire, there was a highly organized diplomatic staff known as the llari, whose main duity was to act as royal messengers. In Dahomey, a similar organization, which performed ambassadorial duties, was referred to as the Wensangum. Diplomatic relations existed between Oyo and Dahomey.

The process of treaty making among African states at times involved cumbersome and solemn processes of oath taking and sacrifices and it was binding, pacta sunt servenda. In some communities like Oyo and Dahomey, as in the early Asian societies, particularly China, hostages were exchanged as basis for assurance 
of the validity and sanctity of treaties. Between the Alafin of Oyo and the King of Dahomey dynastic marriages were tools of diplomatic practices. Treaties were not only sanctimonious, but there were procedures for enforcement as well as that of renunciation. This was so long as the initial conditions upon which the treaties were based remained unchanged, clausula nebus sic stantibus.

Early European contact with Africa witnessed a series of treaty relations both bilateral and multilateral. The negotiations were carried out using established procedures in international relations. More often, the foucs of relations was on trade. From Arab trade in the East African coast through Dutch interest in South Africa; English, French and German interests in the West and other parts of Africa, a concerted and responsible treaty making process was in place up to the late nineteenth century. This, for example, explains the diplomatic encounter between Emir Zubeiru of Adamawa and the French, British and Germans ${ }^{15}$ between Benin and the British, resulting in the Gallwey Treaty of 1872. Afro-European diplomatic relations broke down at the close of the nineteenth century but this cannot obliterate Africa's place in the subject of international relations.

\section{International Relations in Africa in Transition}

The European desire to colonize Africa ushered in a unique and significant period in Africa's international relations. By mid nineteenth century European interest in Africa began to transcend economic interactions to that of political subjugation. Africa became the focal point of European political and military aggrandizement, with Britain, France, Italy, Portugal and Germany at the forefront. The Berlin Conference of 1884-85 by which a geo-political restructuring of Africa was carried out by Europe without consulting with Africans was a breach of relations. Boundaries resembling the European type, defining the European concept of statehood, were established with no concern for indigenous identities. New sovereignties with new concepts were established where hitherto none had existed. Political structures and tenors of administration were established most of which had features that were completely at variance with existing practices and concerns. Africa became a captive continent under the aegis of different colonial powers. The immediate implication of European subjugation of Africa, for Africa's international relations, was to subsume African interest in that of the colonialist. With loss of sovereignty, African states were woven into the diplomatic initiatives and entanglement of their conquerors.

African States fought in the world wars of 1914-1919 and 1939-1945, on which ever side, the political circumstance of the time determined for them. The ancillary status of African states in the international relations of the time was clearly expressed when at the end of the wars tributes were neither expressed in honor of fallen African soldiers nor was compensation made to Africa.

15. S. Abubakar, The Lamibe of Fombina: A Political History of Adamawa, 1809-1901, Zaria : Ahmadu Bello University Press, 1977, pp. 70-75. 
Significantly, new ideologies emerged in Africa to complicate the existing ones. Beyond religion, after the Second World War, the Cold war polarized the international system. Colonized African states may not have had a choice in deciding where to pitch their tents in this divide. But, as much as it was practically possible, African States leaned more towards the powers that were sympathetic to their quest for freedom.

It may be argued that the colonial period was a brief interlude but it was indeed critical to the unfolding history of Africa's International relations. The period saw the emergence of new states, some of which encompassed several indigenous states within one artificially contrived governmental apparatus. The indigenous elite who inherited these structures at independence favored the continuation of these European structures as they guaranteed more power. In a sense too, it may have been more expedient to carry on with an established machinery of government. Elitist Africans were already part of the bureaucracies of colonialism. They had acquired enormous interest for self-preservation and so invariably sought to maintain them. What was now paramount was how to survive in an intricate political network that had been clogged by ideological considerations.

\section{Africa and The Cold War World}

The view is often canvassed of the insignificance of Africa in the international relations chessboard of the super powers. Clapham posits that African states barely figured in the international calculus of the super-powers. ${ }^{16}$ When there was a semblance of inclination towards acting in consideration for Africa it was merely within the simple ambit of African independence versus superpower imperialism. ${ }^{17}$ This implies that Africa did not actually mean much in determining the direction to which the pendulum of international politics should swing but merely stayed in the wings.

This theory of unimportance, of the benevolent receipt of superpower largesse, does not quite bear out the true situation. From the point of view of the capacity for possessing military hardware to affect the military balance in the international system, Africa may not have had much to be of significance. Beyond this, African states were a factor to be reckoned with. They had just emerged from independence at a period, which coincided with the Cold war. The West believed, and mistakenly too, that African interests were still predicated on their association with their former colonial powers. Africa's emergent vibrancy was certainly misunderstood by the West. That partly explains the miscalculation of the West during the Nigerian Civil War, when it was thought that Britain could dictate the trust of the civil war alliances. Nothing seemed to have been learnt by the botched attempt at an Anglo-Nigeria Military pact in 1965. There seemed to have been

16. C. Clapham, Africa and the International System: The Politics of State Survival, Cambridge University Press, 1988, p. 134.

17. Ibid, p.135. 
little realization by the erstwhile western colonialists of the determination by African states to exercise true independence in their international affairs by seeking, if necessary, alternative sources of support. The need to defend newly won independence clearly overshadowed forced colonial alliances.

Most of the new states of Africa had the wherewithal to play a significant role in the international system. They were literarily lush gold mines, with rich natural resources, which were the sinecure of European interests. The large copper deposits of Katanga, the oils of the Sahara regions of Algeria and Morocco were significant in the reckoning of affairs in the international system. Added to this, the new states of Africa were not unmindful of their security in an international environment that was threatened by the mutually destructive capacities of the super powers. It was therefore in Africa's interest to sway the international system for her own security and survival.

African states were not mere onlookers in the international arena. For example, as noted in Naomi, critical to African interest at independence were to assist in keeping disarmament talks going, sway decisions in the United Nations, question traditional methods of diplomacy, see to the modification of rules relating to insurgency and belligerency particularly, in relation to liberation movements; and a complete reform of the existing international world economic order. Of course, African states had the joker of their vastly untapped economies to brandish.

For post independent African states conflict between outright submissions to the whims of erstwhile colonial alliance and charting a new path in the international system had been paramount in their diplomatic strategy. The struggle for independence, particularly in relation to who gave what assistance, had fashioned the diplomatic trust of African states. The Soviet Union was foremost in throwing her weight behind African states that professed socialism as a weapon to fight oppression. This accounted for the socialist character of Algeria and Tanzania, which pre-disposed them to formal support from the Soviet Union.

The option for non-alignment by some African states was strategically motivated. In fact, non-alignment was more conceptual than real. States pursued non-alignment only to the extent that it was strategically convenient to do so. The level of commitment to non-alignment was a factor of the degree of control over domestic policies as well as geo-political security. Otherwise, non-alignment was merely an instrument of diplomacy by African countries in the international arena. The Horn of Africa presents a classic example of high security stakes, providing an opportunity to play one super-power against the other. In the Ethiopia-Somalia crisis, Soviet arms and personnels were used interchangeable in the course of the crisis, as domestic interests and ideology changed hands in the antagonizing states.

For Franco-phone Africa, analysts may have viewed attachment to the colony as significantly portraying Franco-phone African states as puppets. This may be missing the point. A large number of Franco-phone states did enter into formal military agreements with France at independence. Financial arrangements by which Franco-phone African states belonged to a common currency zone i.e. the 
CFA Franc also assured 'big brother' guarantee in financial matters. But the relevance of France in the activities of the French states was a factor of prevailing relations. By late 1980s only a handful of French states such as Cameroon, Central African Republic, Djibouti, Gabon, Cote divoire, Senegal and Togo retained defense agreements with France. Between 1960 French military aid to Africa was static while between 1977 and 1986 there was an increase. However, much of it was recycled to France in form of arms sales. ${ }^{18}$ Rather than being a case of dependence, the character of French relations should be viewed more from the point of inter-personal relationships than an avid policy of state.

The resort to the Soviet Union by African states was essentially a diplomatic initiative occasioned by Africa's reading of the barometer of the international system and certainly not borne out of subservience to any group. The diplomacy in the Nigeria Civil War 1967, which enjoyed abundant Soviet support, was a question of expediency. In Angola, Mozambique and Guinea-Bissau, insurgent warfare was waged against the intransigence of Portugal to disengage from colonial rule in Africa. In the ensuing resistance it was obvious that the western powers were not prepared to offer support against Portugal, which was a NATO ally. African states had in the circumstance to find support in the Soviet bloc. In fact in some cases, anti-Communist claims by some African leaders became a ready ticket for western patronage. For example, the Mobotu regime in Zaire was quick enough to sound and alarm against Soviet support of Angola and the possibility of Soviet expansion in Central Africa. In view of Western interest in the vast mineral resources of Zaire, her support was a foregone event. In 1977 and 1978 Western forces had to intervene directly in Zaire to save the Mobotu regime from collapsing.

So long as the cold war subsisted, African states had no other option than to pursue a survivalist policy in the international system. The cold war scenario provided ample impetus for African maneuvers in the international system, which was certainly not a case of passiveness. When the cold war ended in 1989, with the collapse of the Soviet Union, the global conditions on which African diplomacy had been predicated no longer existed. The diplomatic complications that seemed intractable during the Cold war quietly fizzled out; the dependence on the global division as a factor of policy thrust in Africa gave way. Principal areas of crisis had respites Ehtiopia's Megistu gave up his tenuous hold to power; Namibia became independent Somali's Siad Barre fled his country leaving it in disarray. There was political reprieve in South Africa; Eritrea gained independence- the gains are countless. A new world order had set in and the international calculus had also changed calling for further adjustment from African states.

\section{Inter-Realtions in Independent Africa}

The foundation and systematic evolution of post-independence inter-African relations can be dated to 1960, often regarded as Africa's year. With the emergence of sovereign states in Africa each state began to conceive a perception of Africa's future.

18. Ibid, p. 97. 
Across the continent were diversities of language, culture, religion and economic inequalities. $^{19}$ Opinions were diverse. In 1963, the attempt to crystallize the multiplicity of views into a workable formula led to rivalries and Africa was spilt into three rival blocs-the Casablanca group, the Monrovia Group and the Brazzaville Twelve. These could simply be tagged as moderates and radicals. Despite these contending perceptions a major milestone in African diplomacy was the establishment of the OAU in Addis Ababa in that year.

Difficult as the terrain may have been, as $\mathrm{Agbi}^{20}$ has rightly noted there are good reasons to believe, as the founding fathers did, that the OAU would achieve positive results in Africa. After all, the organization was not imposed. There was no element of compulsion rather it was founded on a careful regard for the political susceptibilities of African States. ${ }^{21}$ The scope of commitment and long-term interests were full affirmed in Article III namely, adherence to the sovereign equality of all member-states, non-interference in the internal affairs of states; respect for the sovereignty and territorial integrity of each state; and inalienable right to independent existence. African states also resolved to settle intra-African disputes peacefully by resorting to traditional African age-old strategies of negotiation, mediation, conciliation or arbitration. ${ }^{22}$ African states were cautious enough to realize the dangers of the cold war and so toed the path of restraint in African alliances so as not to impede the continent's freedom of action in the international system.

Understanding individual perceptions and attitude, to these events and how they impacted on relations between African states can best be appreciated as certain key events played out themselves in the continent. For the purpose of clarity we shall take a few cases for analysis.

\section{Case I: Border Disputes}

The European imposed international boundaries in Africa constituted a major area of conflict after independence, posing a challenge to continental peace. The magnitude and character of these disputes lent credence to the possibility that African states were progressively going to be ravaged by endless border disputes. The response by each states was a factor of the status quo or rather the state of the individual country in relation to boundary claims and irredentism. The picture that therefore emerged in inter-state relations in Africa was a reflection of how the various states of Africa were positioned in terms of the realities of their boundaries.

In the Algeria-Morocco dispute, Morocco laid claim to an Algerian held territory in the Sahara. Morocco based its claim on fluid territorial arrangement between the French and the Sultan of Morocco in the colonial era. Indeed, Morocco had a temporal perception of the Sultan's territory, which was not defined strictly by geographical considerations. In addressing this issue, Morocco had signed an

\footnotetext{
19. Z. Cervenka, The Unfinished Quest for Unity: Africa and the OAU, London: 1977, pp. 1-11.

20. S.O. Agbi, The OAU and African Diplomacy 1963-1979,Ibadan: Impact Publishers, 1986, pp. 57-60.

21. Cervenka, f.n. no. 19, p.3.

22. Ibid, p.10.
} 
agreement with a war wearied Government, the Provisoire de la Rapublique Algerienne (GPRA) in Algeria in 1961. Expectedly, Algeria reneged on the agreement in 1992 and this provided the excuse for the Morocco-Algeria war.

Political circumstances and interests determined the attitudes of African States in the Morocco-Algeria War. Tunisia and Egypt were constrained by their commitments to the Arab League. For Ethiopia, which had a similar internal crisis to contend with, caution was employed. Emperor Haille Selasse of Ethiopia called for conciliation and urged the need to foster unity in the continent. Ghana used the opportunity to reiterate her call for the Union Government of Africa that would make territorial boundaries obsolete and superfluous. ${ }^{23}$ This was understandable given Ghana's problems with Ivory Coast over the Ewe people. When the OAU finally set up and Ad Hoc Commission on the Algeria-Morocco dispute it was plagued by diverse arguments and interests. Characteristically, the Commission lacked cohesion and did not assist the settlement of the Algeria-Morocco dispute.

The Ethiopia-Somali dispute like the Morocco-Algeria crisis also stretched African initiatives to their limits. The crisis had its roots in the unpleasant legacy of artificial boundaries drawn by the colonial powers in the $19^{\text {th }}$ century. When war erupted in the 60's it arose mainly because of a Pan-Somali movement, which was aimed at a Greater Somalia State encompassing territories in Ethiopia and Kenya. Even though Ethiopia had been the champion of continental unity, she rejected the Somali claim as, outrageous. Between Ethiopia and Kenya evolved a mutual understanding, which was sealed in an "Agreement of Co-operation and Mutual Defence Assistance" in 1963. Somalia saw this agreement as being directed against her and she intensified her search of alliances and support. In 1975, Somalia signed an agreement with Russia for military assistance. When Soviet troops were later expelled in Somalia in 1977, the Soviets immediately won the embrace of Ethiopia, with the active participation of Cuba. This also attracted the friendship of Libya, which in turn brought Sudan and Somalia together. In the circumstance, the United States intensified her interest in the horn of Africa The cold war scenario freely played out itself in the Horn of Africa. In the midst of conflicting African interests, an African solution could not be found. The proposal for conciliation and the establishment of a demilitarized zone between Ethiopia and Somalia did not receive the co-operation of both countries and so the war continued to its logical end.

It should be noted that even though Somalia's claim did not enjoy popular support, she enjoyed the sympathy of Egypt to which Somalia reciprocated by supporting the Arab cause with respect to Israel. It further gave Egypt a diplomatic leverage in the Horn of Africa. As Egypt continuously projected the Somali cases as demonstrating western and neo-colonial influence in the region, she assumed the image of a liberation fighter. ${ }^{24}$ For Tanzania, she was unfavorably disposed towards Somali. This was because of her historical link with Kenya as well as her desire to stem the possibility of the Somalis in Arusha and Tanga seeking to secede.

23. S. Touval, The Boundary Politics of Independent Africa, Howard: Howard University Press, 1972, p. 134.

24. Ibid, p. 135. 


\section{Case II: Liberation Movements}

Nothing seems to have tasked inter-African relations more than liberating the last vestiges of colonialism in Africa. The problem had been obvious since 1960 , while the bulk of the continent attained independence only the island of Madagascar was so favoured among the south African States. The issue of liberation thus became an integral part of the OAU agenda resulting in the formation of a Liberation Committee in 1963 as a forum for channeling support to the peoples of Southern Africa. The Liberation Committee had its headquarters at Dar es Salaam in Tanzania. The task of liberation of independence (UDI), Angola, Mozambique, Namibia and South Africa whose military might dominate and threatened the security of the entire sub-region.

The need for a common front brought about a collective arrangement of front line states. Within this matrix the most prominent were Tanzania and Zambia who had obvious geo-political reasons for being frontline states. Tanzania's involvement was borne out of the need for friendship with ideologically sympathetic regimes. Tanzania's common border with Mozambique was a ready invitation to a regime that was desirous of socialism. The question of ideology was critical to Tanzania's support for the FRELIMO leadership. Zambia's economic reality, with a landlocked copper belt whose access to the sea depended on rail lines through South African territories made her an avowed promoter of liberation in Southern Africa. Both Tanzania and Zambia therefore found bases for corporation even though differing in diplomatic procedures and tactics as dictated by geo-political realities.

In Zimbabwe, the contending parties were the Zimbabwe African National Union (ZANU) led by Robert Mugabe and the Zimbabwe African Peoples Union (ZAPU) led by Joshua Nkomo. In spite of the divergence in international linkages, both movements were encouraged to form the patriotic front in 1976. In the operations of the frontline states, while Tanzania preferred a more radical approach, Zambia that was obviously walking a tightrope, having a disadvantaged geo-political circumstance, sought a moderate approach to the decolonization process in Southern Africa.

The Angolan Crisis was equally profound in exposing the intricacies in inter-African relations. The Angolan resistance to Portugese rule revolved around the MPLA (Popular Movement for the Liberation of Angola), FNLA (National Front for the Liberation of Angola), UNITA (National Union for Total Independence of Angola). Support by African states for liberation movements in Angola had remained testy due to ideological cleavages. The liberation movement enjoyed varied external support in Africa. For example, FNLA received trainings in Tunisia and Zaire while MPLA received training in Morocco and Congo and already got support from Algeria. The OAU attempt to reconcile these parties had always met with failure. Subsequently, these rival factions cultivated strong ideological leanings. The MPLA aligned with Marxist and leftist governments while the FNLA enjoyed western support. UNITA, a third party may be said to have had the least followership. 
The litmus test came in 1975. Portugal had signed a trilateral accord with all parties and fixed independence for November 11,1975, which was to be preceded by elections. Peaceful election was shattered when the United States and the Soviet Union pitched tents in Angola. UNITA had support from China and South Africa. MPLA had Cuban support. The situation brought a division among African States. OAU intervention was stalemated. Consequently, the final decision regarding Angola's independence had to be decided on the battlefield.

Relations between African States and Angola were determined by individual concern for security. Zaire's later overtures to Angola were based on Angola's pledge to keep off ex-Katanga gendarmes. South Africa's relations with Angola were based on her security perception in the region particularly the area around Southern Angola. Mozambique's support for Angola strengthened the capacity of front line states against apartheid South Africa. The presence of Cuban troops was major thereat to South Africa. In the midst of this volatile situation, the Chester Crocker initiative was most welcome leading to the signing of the Tripartite Agreement by which South Africa withdrew from Angola while accepting a timetable for Namibian independence. The agreement also included withdrawal of Cuba from Angola.

In fact, the end of the cold war meant that Africa needed to look more inward for her solutions. By 1998, for example, Algeria and Morocco were already on the part to reconciliation. These signs of settlement brought about considerations for an Arab Maghreb Union comprising Mauritania, Morocco, Algeria, Tunisia and Libya. The prospects of regional co-operation in the resolution of dispute ran high in West Africa when in 1990, the member states of ECOWAS namely Nigeria, Ghana, Guinea, Sierra Leone and Gambia initiated a military coalition known as ECOMOG to restore peace in war torn Liberia. The activities of ECOMOG in Liberia revealed age-long cleavages in West Africa, as co-operation between Anglophone and Francophone states was very tenuous.

\section{Conclusion}

The study of African international relations may have suffered neglect but this has not diminished the breadth and veracity of its content. The parameters for its study are neither far-fetched nor do they exhibit peculiarities or difficulties in their application. The unit of operation in the international system is the state. The prescription attendant to such a unit of participation plays themselves out in full in the international system.

Africa's past has certainly not had a proper appreciation and understanding. There is an obvious ignorance of the African past. The African past was not historically naked. The image of Africa as the Dark Continent, cloaked in mystery, was merely a colonial myth for convenience. Africa did have a vibrant past. The political and economic structure evolved in response to the environment and changing circumstances. Inter-actions within and between African people were systematized and appropriately coordinated. Rules and regulations concerning 
procedure were instituted and promptly executed. African international relations had all the trappings associated with diplomacy.

Colonialism was simply an episode in the history of African diplomacy. It could be argued that Africa's eventual capitulation to colonial rule marked the breakdown of diplomacy, culminating in war and defeat. Initial interaction with Europe surrounding trade and other well conceived bi-lateral relationships are evidence of a sophisticated diplomatic terrain in Africa. The colonial period may have indeed diverted the thrust of African initiatives as well as the indigenous control by African States of their destinies. But the impact of the African experience remains germane to the evolution of African international relations. Ideological wrangling in the international system coupled with Africa's search for a new identity galvanized and revolutionized the content of African diplomatic practice. Emergent Africa related with the outside world in full consideration of the national interest, it had always sought to promote and preserve. 